\title{
Antifungal effect of Polar and non polar extracts of Aframomum Sceptrum on Two Isolates of Oil Palm
}

\section{*110KOGBENIN, OB; EMOGHENE AO; OKOGBENIN EA; AIREDE CE;}

\author{
${ }^{I}$ Nigerian Institute for Oil Palm Research (NIFOR), Plant Pathology Division, P.M.B. 1030 Benin City, Edo State. Nigeria \\ ${ }^{2}$ Department of Microbiology, University of Benin, Benin City. Edo State. Nigeria. \\ ${ }^{3}$ Nigerian Institute for Oil Palm Research (NIFOR), Biochemistry Division, P.M.B. 1030 Benin City, Edo State. Nigeria.
}

KEY WORDS: Oil palm, Antifungal, Phytochemical, DMSO, Pathogens.

\begin{abstract}
In different parts of the world, attention is being paid to exploitation of higher plants as biodegradable fungicides in the control of most plant pathogenic fungi. Different spices of the Zingiberaceae family have been tested for their antifungal properties, but there exists little or no information on the antifungal potential of a particular member of that family; Aframomum sceptrum on fungal pathogens of some economic important palms in Nigeria. In this study, the phytochemical composition of the seed extracts of this spice was analyzed by standard methods while the antifungal activities of polar and non polar extracts of the spice was tested on two major isolates affecting the Oil palm, Fusarium oxysporum f.sp elaeidis and Hypocrea lixii (IMI 501885) Cold extraction using Acetone, Ethanol, Hexane, Methanol, and Diethylether solvents were used in the seed extract preparation. The broad spectrum fungicide, Mancozeb ( $80 \%$ wettable powder) was used as the positive control while the negative control was Dimethyl sulphoxide. The Dimethyl sulphoxide was also used to reconstitute the solvent extracts by dissolving the extracts and fungicides in appropriate amount of $15 \%(\mathrm{v} / \mathrm{v})$ to obtain a concentration of $0.0624 \mathrm{~g} / \mathrm{ml}$. The phytochemical screening revealed the presence of the following phytochemicals in different quantities; Alkaloids, Terpenoids, Anthraquinones, Flavonoids Tanins, Saponins. Results obtained showed that all the extracts had a significantly higher antifungal effect $(\mathrm{p}<0.05)$ than the broad spectrum fungicide, Mancozeb at 2000ppm. Non polar hexane seed extract had the highest percentage inhibition of $60.26 \%$ on Hypocrea lixii (IMI 501885 while the Polar ethanolic extracts with a percentage inhibition of $52.73 \%$ on Fusarium f.sp elaeidis. Amongst all the extracts used in this study, the seed extracts that gave a low percentage inhibition of $42.45 \%$ was the non -polar acetone seed extract on Fusarium oxysporum fsp. elaeidis and methanol extract on $H$.lixii with the least percentage inhibition of $42.31 \%$. The implications of these findings are discussed. () JASEM
\end{abstract}

\section{http://dx.doi.org/10.4314/jasem.v18 i2.4}

Introduction: The Oil palm (Elaeis guinnensis) of the family Arecaceae is a major economic palm of the world, with their oils as their major economic products (Nair, 2003). They are perennials, monocots and are grown majorly in tropical regions of the world with heights up to 1000 meters above sea level (Nair et al., 2003). The palm is generally regarded to as the tree of life because of its diverse way in which it can be utilized both in small-scale and large-scale. It is native to West and Southwest Africa (De Marco et al., 2007) and it is classified as the most important oil crop in the world (Oil world, 2008). The palm is classified into three separate groups based on the shell thickness of its fruit: Dura (thick shell), Tenera (relatively thin shell) and Pisifera (absence of shell). Tenera, the genetically formed hybrid between Dura and Psifera has higher oil extraction efficiency (Hartley, 1988; Harminder et al., 2010) and The empty fruit bunch, the shell and fiber that remain after oil extraction are used for mulching, manuring and as fuel (Ravi Menon et al., 2003). The leaves of Oil palms are used for making brooms, roofing and thatching, basket and mats. The sap tapped from the tree called "The palm wine" can be allowed to ferment and distilled into a gin known as "Akpetesin" in Ghana and "Ogogoro" in Nigeria (Simon Heap, 2008). Plant diseases play a direct role in the destruction of natural resources in agriculture and in particular, pathogens cause important losses, fungi being the most aggressive (Abou-Zeid et al., 2008). Fungi often attack these palms either at the pre-nursery, nursery and adult palms stages often 
resulting in an indirect yield reduction by affecting fruit quality. The Vascular wilt disease of Oil palm first described by Wardlaw in 1946 is caused by Fusarium oxysporum f. $s p$ elaeidis (Ho and Varghese, 1986) and it is the most damaging disease of Oil palm in Africa (Flood, 2006; Tengoua and Bakoumé, 2008), causing up to $70 \%$ mortality. Several Western and Central African countries are particularly affected by vascular wilt (Aderungboye, 1982; Corley and Tinker 2003; Tengoua and Bakoumé, 2008; de Franqueville et al., 2011). Some other fungal isolates from the exocarp of deteriorating palm fruit is Hypocrea lixii (anamorph Trichoderma harzianum) Chaverri and Samuels, (2002). Trichoderma harzianum as it is the most frequent Trichoderma species in majority of samples world1 wide (Zachow et al., 2009).Many of the genus are ubiquitous inhabitants of soils, decaying plant matter and debris (Harman et al., 2004). They have been found to colonize and cause infections on oil palm seeds in germinators and storage rooms (Ghosh, 2009) especially in subtropical and tropical regions like Nigeria (Cirumalla et al., 2011; Gomathi and Ambikapathy, 2011). Fungicides have been used over time by farmers to reduce the activities of these pathogens however; the extensive use of fungicides in plant protection against fungal disease generates long-term residues in food and in the environment (EFSA, 2009; Petit et al., 2008). In the annual EU report, EFSA (European Food Safety Authority), where vegetables and fruits of 27 countries were surveyed for pesticides contamination, the results highlighted that dithiocarbamates are among the most common residual contaminants (EFSA, 2009). The abusive use of such compounds in agriculture has mobilized public concern because of the harmful potential of such substances in the environment and in the food chain representing a risk for human health (EFSA, 2009). A major toxicological concern with respect to mancozeb and other dithiocarbamates is its primary metabolite, ethylene thiourea (ETU), shown to cause structural and functional alterations of gonads and thyroids of humans (Kackar et al., 1997; Baligar et al., 2001). Ethylene thiourea is very soluble and moderately mobile in the environment, it potentially could be found in drinking water from both surface water and groundwater sources close to some farm lands. It was measured at $0.21 \mathrm{ppb}$ in the raw water from one public drinking-water well. $($ Detection limit $=0.1 \mathrm{ppb}($ EPA 2005). Studies have shown the importance of natural chemicals as a possible source of non-phytotoxic, systemic and easily biodegradable alternative fungicides (Loizzo et al., 2004). Mushin et al., 2001; Okigbo and Emoghene, 2003 reported that many plant extracts have been demonstrated to be effective in the control of several plant diseases as they exhibit a number of chemical and biological advantages as fungicides. Biological investigations carried out on several species from the genus Aframomum, of the family Zingiberaceae revealed their antiparasitic, antifungal, antibacterial and antiviral properties. (Cousins and Hoffman, 2002; Okwu et al., 2003). Further studies showed their analgesic, aphrodisiac, antiinflammatory, antioxidant, antiulcer and antiprotozoal efficacies (Singh et al., 2007; Cheikh et al., 2011) while the seeds of Aframomum species have been found to contain phytochemicals (Fasoyiro and Adegoke, 2007). Exploitation of antifungal agents from plant metabolites is considered to be an approach to identify novel fungicides which meet environmental requirements as well as help control plant pathogenic organisms. This invitro study seeks to investigate the possibility of using the seeds of this plant to control two economically important pathogens of the Oil palm, Fusarium oxysporum and Trichoderma sp.

\section{MATERIALS AND METHODS}

Sample collection: Infected plant parts showing disease symptoms were identified from different parts of the plant, samples were taken from the mesocarp of rottening palm fruits, while other samples were collected from the roots, the foliar parts and soil area from some infected Oil palms showing symptoms of vascular wilt disease. A pre-sterilized soil probe was used to collect five grams $(5 \mathrm{~g})$ of soil with a depth of about four inches from the perimeter base of each Oil palm sampled for this experiment. The soil samples were then placed in sterile polyethylene bags, labeled and sealed by the bags. Diseased root samples collected were cut with the use of a sterile scissors and the samples placed in separate labeled sterile sample bags and sealed.

Culture media Preparation and Sterilization of materials: The culture media used for this study is the general purpose media, the Potato dextrose agar (PDA). The media was prepared according to manufacturers' instructions and sterilized using a portable Gallenkamp autoclave at $121^{\circ} \mathrm{C}$ at $15 \mathrm{psi}$ for 15 minutes and allowed to cool to a temperature of about $23^{\circ} \mathrm{C}$ before using (Obagwu et al., 1997). Autoclavable materials such as McCartney bottles, beakers, and distilled water were sterilized using the same autoclave as above under the same condition of 
$121^{\circ} \mathrm{C}$ at 15 psi for 15 minutes while Petri dishes and other metal apparatus such as spatula and forceps was sterilized using hot air oven at a temperature of $160^{\circ} \mathrm{C}$ for 2 hours. The wire loops were sterilized by heating in the blue flame of a Bunsen burner until red-hot and allowed to cool before using.

Isolation and Identification of Test organisms: Thin sections ( $2 \mathrm{~mm}$ diameter) were cut from the peripheral areas of diseased lesions of the samples using a sterile blade and sterilized for one minute in already prepared $30 \% \mathrm{v} / \mathrm{v}$ sodium hypochlorite solution and rinsed in three changes of sterile distilled water (Kinkel and Andrews, 1988) and placed on sterile filter papers in order to blot out traces of water. In the sterile Laminar flow chamber, the samples were transferred aseptically using a sterile wire loop into pre-sterilized $9 \mathrm{~cm}$ diameter Petri plates containing solidified Potato Dextrose agar (PDA) supplemented with streptomycin. The plates were incubated at ambient conditions of light and temperature of $25 \pm$ $2^{\circ} \mathrm{C}$ (Abou-Zeid et al., 2004). The cultures were monitored on a daily basis until growths were observed. Individual fungal colonies were purified by aseptically sub culturing into fresh PDA plates. The plates were further allowed to stand for another seven to ten days to allow for proper sporulation and consequent identification while some cultures were stored in PDA slants and refrigerated at $4^{\circ} \mathrm{c}$ for future use. Isolates of Fusarium oxysporum were identified based to their cultural, morphological and microscopical characteristics as described by Nelson et al., (1994) and compared with texts from Common wealth Mycological Institutes identification Manual while the Trichoderma sp. was identified by CABI, Surrey, UK as Hypocrea lixii (anamorph Trichoderma harzianum)with IMI No. 501885. Snap shots of the spores of these organisms as shown on plate 1.0 were captured using a motic camera attached to a microscope.

Extract Preparation: Fresh seeds of Aframomum sceptrum were obtained from a market in Benin City, Edo State, Nigeria and identified by a botanist at University of Benin, Benin City. The seeds were harvested from the pods by hand picking. They were washed thoroughly with sterile distilled water; oven dried at a temperature of $45^{\circ} \mathrm{C}$ and pulverized using a Lexus mixer grinder with model No: MG 2053 to a fine powder form according to the method of Wokocha and Okereke, 2005. Thirty grams (30 g) of the fine powder was weighed using an analytical weigh balance with model NO: ALC 201.3 15038730. Five different extracting solvents of analytical grade were used to prepare the seed extracts (Bautista et al., 2003). The solvents include Ethanol, Diethyl ether, Hexane, Acetone and Methanol. Fifty (50mls) of each solvent was measured using a clean calibrated cylinder and poured carefully into sterilized $250 \mathrm{ml}$ Erlenmeyer flask each. The already weighed powder $(30 \mathrm{~g})$ of the seed powder was then dissolved in the respective solvents to give $60 \% \mathrm{w} / \mathrm{v}$. The flasks were sealed with a sterile foil paper and held tightly with rubber bands. The labeled extracts were then placed in an orbit shaker with model No: 3521 for 24 hour duration to allow for uniform extraction of the active ingredients. The solvents were recovered using a buchii rotary evaporator Manufactured by Bibby Sterlin LTD., England with model No: RE 100 at 40 ${ }^{\circ} \mathrm{C}$ under vacuum and the extracts reconstituted by dissolving in appropriate amount of $15 \%$ (v/v) dimethyl sulphoxide to obtain a concentration of $0.0624 \mathrm{~g} / \mathrm{ml}$. Dimethyl sulphoxide an organosulphur compound which is colorless with a molecular formula of $\left(\mathrm{CH}_{3}\right)_{2} \mathrm{SO}$ dissolves polar and non polar compounds (Novak, 2002). This dissolution in DMSO did not affect the mycelia growth of the test microorganisms negatively; this was observed during the preliminary studies and confirmed by the control experiments.

Antifungal activity assay using Pour Plate Method A micropipette was used to measure $1 \mathrm{ml}$ of each of the solvent extracts into already prepared $10 \mathrm{ml}$ of PDA medium in a glass test tubes, the mixture was shaken thoroughly and poured into a labeled sterile Petri plate in a laminar flow chamber .This procedure; food-poisoned technique was carried out according to Nene et al., 2000. The amended medium was swirled gently to ensure thorough mixing of the contents before solidification of the medium. Three (3) $\mathrm{mm}$ disc of three-day-old culture of the fungus, Fusarium oxysporum and Hypocrea lixii IMI No. 501885 was harvested using a $3 \mathrm{~mm}$ sterile cork borer and each organism was aseptically inoculated unto the centre of the labeled Petri plates in an inverted position in order for the mycelium to achieve greater contact with the culture medium. The position of the disc was marked on the base of the dish with a marker pen and two perpendicular lines were drawn passing through the marked position, this line was used measuring the radial growth of the organism. The experiment was carried out in triplicates and the plates were incubated at temperature of $28 \pm 2^{\circ} \mathrm{C}$. Two controls were set up, the PDA medium modified with the $1 \mathrm{ml}$ of DMSO4 served as the negative control and the 
other, PDA amended medium with $1 \mathrm{ml}$ of the fungicide, mancozeb ( $80 \%$ wettable powder) served as the positive control using the recommended dosage of $2 \mathrm{~g} / \mathrm{l}$ (2000ppm) for antifungal activity. Daily measurements for seven days of the mycelia extension of the individual cultures were taken with the aid of a meter rule by measuring colony diameters along the two perpendicular lines drawn on the reverse side of the plates and the average means were calculated for each duplicate and recorded. The percentage inhibition was calculated as percentage of the difference between the radial growth of the isolate when inhibited and the radial growth when uninhibited, for each isolate using the formula:\% Inhibition $=100($ Control - Treatment $) /$ Control (Singh and Tripathi 1999).

The values of percentage inhibition of the test and controls were compared for each test sample. The difference in their percentage inhibition gives a reflection of the extent of inhibition by the extracts on each isolate.

Phytochemical Screening Extracts: Qualitative and quantitative phytochemical analysis was carried out on the five different extracts for Six (6) phytochemicals each bringing the total phytochemicals screened to thirty. The screening was carried out in the Biochemistry laboratory of Nigerian Institute for Oil Palm Research (NIFOR.)Benin City and in the Chemistry laboratory of the Nigerian Institute for Science Laboratory technology (NISLT) Ibadan, Nigeria. The extracts were evaluated for the presence of Alkaloids,
Flavonoids, Saponins, Anthraquinone, Tannins, and Terpenoids using standard procedures as described by Sofowora 1993, Trease and Evans, 1989, Harborne, 1998 and Ghani 1998).

Statistical analysis: Data obtained was subjected to biostatistical analysis using the one-way ANOVA, while significant differences among the means were determined by using Duncan's New Multiple Range (DMR) Test as outlined by Obi, 2002. The statistical analysis was conducted with SPSS software (SPSS 17, USA set at significant levels of 0.05).

\section{RESULTS AND DISCUSSION}

Different fungi were isolated from the diseases leaf lesions of oil palm leaves, roots, soil area as well from the mesocarp of oil palm fruit showing symptoms of deterioration. Amongst these fungi isolated and tested for this invitro antifungal investigation were Fusarium oxysporum f.sp eleaidis (Summerell et al., 2003) and Trichoderma sp. further identified as Hypocrea lixii based on: CABI Identification Report; Hypocrea lixii. (IMI number 501885): The sample was identified using partial ITS DNA sequencing analysis. The sequence obtained showed $100 \%$ identity to multiple ITS sequences reported from Hypocrea lixii including a number cited in peer-reviewed publications (Chaverri and Samuels, 2002). The isolate showed the anamorphic state of Trichoderma harzianum. Plates 1 and 2 below, shows the pictomicrograph capture of isolates

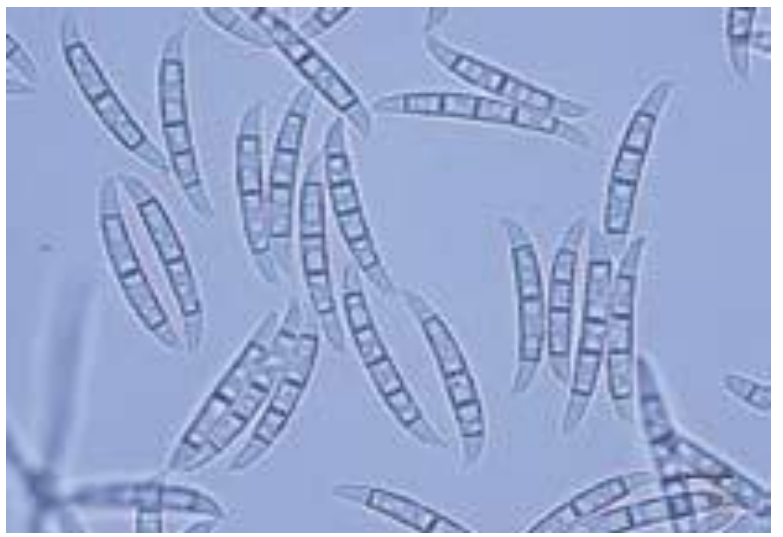

Plate 1: Pictomicrograph capture $F$. oxysporum showing slightly sickle-shaped macroconidia .

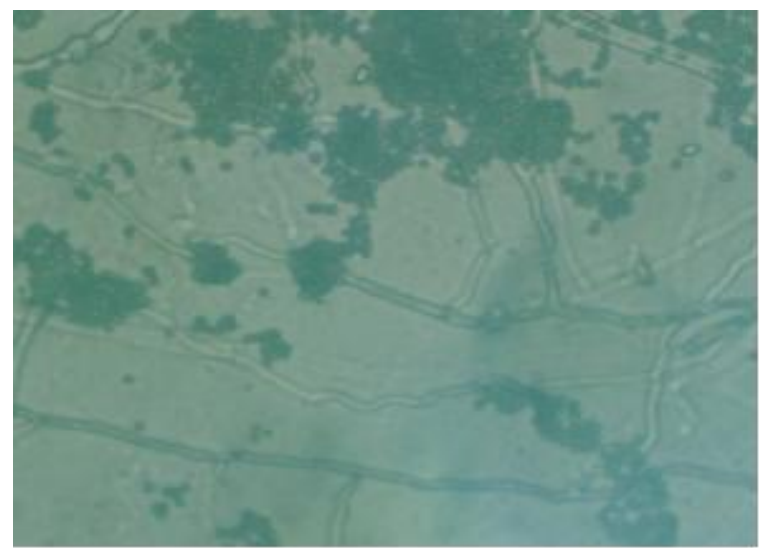

Plate 2: Pictomicrogh capture of Hypocrea lixii IMI 501885 
Results on tables 1 and 2 respectively shows the effect of the five seed extracts of A. sceptrum on the mycelia growth within a period of seven days of monitoring and incubation under temperature of $28 \pm 2^{\circ} \mathrm{C}$.

Table 1 Average mycelia measurement in $\mathrm{cm}$ for each extract during the period of seven days on Fusarium oxysporum.

\begin{tabular}{|c|c|c|c|c|c|c|c|c|}
\hline Extracts & Day 0 & Day 1 & Day 2 & Day 3 & Day 4 & Day 5 & Day 6 & Day 7 \\
\hline $\mathbf{N}$ & $0.60 \pm 0.00$ & $1.05 \pm 0.05$ & $2.00 \pm 0.00$ & $2.80 \pm 0.10$ & $3.45 \pm 0.05$ & $4.25 \pm 0.05$ & $4.95 \pm 0.25$ & $5.5 \pm 0.10$ \\
\hline $\begin{array}{l}\text { Control } \\
\text { P } \\
\text { Control }\end{array}$ & $0.60 \pm 0.00$ & $0.60 \pm 0.00$ & $0.70 \pm 0.00$ & $1.30 \pm 0.10$ & $1.90 \pm 0.20$ & $2.50 \pm 0.20$ & $3.00 \pm 0.30$ & $3.60 \pm 0.30$ \\
\hline ACE & $0.60 \pm 0.00$ & $0.70 \pm 0.00$ & $0.95 \pm 0.05$ & $1.40 \pm 0.00$ & $2.00 \pm 0.10$ & $2.35 \pm 0.15$ & $2.65 \pm 0.05$ & $3.00 \pm 0.00$ \\
\hline ETH & $0.60 \pm 0.00$ & $0.65 \pm 0.05$ & $1.00 \pm 0.00$ & $1.35 \pm 0.05$ & $1.85 \pm 0.05$ & $2.20 \pm 0.10$ & $2.30 \pm 0.00$ & $2.60 \pm 0.00$ \\
\hline MET & $0.60 \pm 0.00$ & $0.70 \pm 0.00$ & $0.80 \pm 0.00$ & $1.20 \pm 0.00$ & $1.70 \pm 0.05$ & $2.05 \pm 0.05$ & $2.45 \pm 0.05$ & $2.85 \pm 0.05$ \\
\hline HEX & $0.60 \pm 0.00$ & $0.70 \pm 0.00$ & $0.85 \pm 0.05$ & $1.45 \pm 0.15$ & $1.80 \pm 0.05$ & $2.05 \pm 0.05$ & $2.30 \pm 0.10$ & $2.75 \pm 0.05$ \\
\hline DEE & $0.60 \pm 0.00$ & $0.65 \pm 0.05$ & $0.85 \pm 0.05$ & $1.30 \pm 0.00$ & $1.70 \pm 0.00$ & $2.10 \pm 0.00$ & $2.40 \pm 0.00$ & $2.7 \pm 0.00$ \\
\hline
\end{tabular}

*Data are given as mean of radial growth for three readings (triplicates), values \pm are standard errors of mean (SEM) of triplicates

Table 2 shows the average mycelia measurements in $\mathrm{cm}$ for each extract during the period of seven days on Hypocrea lixii (501885)

\begin{tabular}{|c|c|c|c|c|c|c|c|c|}
\hline Extracts & Day 0 & Day 1 & Day2 & Day 3 & Day 4 & Day 5 & Day 6 & Day 7 \\
\hline N Control & $0.60 \pm 0.00$ & $1.20 \pm 0.00$ & $2.65 \pm 0.05$ & $3.00 \pm 0.00$ & $3.40 \pm 0.10$ & $3.70 \pm 0.10$ & $3.80 \pm 0.10$ & $3.90 \pm 0.10$ \\
\hline P Control & $0.60 \pm 0.00$ & $0.70 \pm 0.10$ & $1.50 \pm 0.20$ & $1.80 \pm 0.10$ & $2.05 \pm 0.15$ & $2.25 \pm 0.25$ & $2.35 \pm 0.15$ & $2.50 \pm 0.20$ \\
\hline ACE & $0.60 \pm 0.00$ & $0.65 \pm 0.05$ & $1.50 \pm 0.10$ & $1.65 \pm 0.15$ & $1.85 \pm 0.25$ & $1.95 \pm 0.15$ & $2.15 \pm 0.25$ & $2.15 \pm 0.25$ \\
\hline ETH & $0.60 \pm 0.00$ & $0.60 \pm 0.00$ & $1.00 \pm 0.00$ & $1.25 \pm 0.05$ & $1.30 \pm 0.00$ & $1.40 \pm 0.00$ & $1.55 \pm 0.15$ & $1.70 \pm 0.00$ \\
\hline MET & $0.60 \pm 0.00$ & $0.70 \pm 0.00$ & $1.20 \pm 0.10$ & $1.45 \pm 0.15$ & $1.65 \pm 0.25$ & $1.80 \pm 0.20$ & $2.10 \pm 0.30$ & $2.25 \pm 0.35$ \\
\hline HEX & $0.60 \pm 0.00$ & $0.60 \pm 0.00$ & $0.80 \pm 0.00$ & $1.00 \pm 0.00$ & $1.10 \pm 0.00$ & $1.10 \pm 0.00$ & $1.40 \pm 0.00$ & $1.55 \pm 0.05$ \\
\hline DEE & $0.60 \pm 0.00$ & $0.60 \pm 0.00$ & $0.85 \pm 0.05$ & $1.05 \pm 0.05$ & $1.40 \pm 0.10$ & $1.45 \pm 0.05$ & $1.65 \pm 0.05$ & $1.80 \pm 0.00$ \\
\hline
\end{tabular}

*Data are given as mean of radial growth for three readings (triplicates), values \pm are standard errors of mean (SEM) of triplicates

Key:

N Control ; Negative control (Dimethyl sulphoxide)

P Control; Positive control. Fungicide

Ace; Acetone

Eth; Ethanol

Met; Methanol

Hex; Hexane

Dee; Diethyl ether

On table 1 above, the extracts and fungicide had significant $(\mathrm{P}<0.05)$ antifungal effect on Fusarium oxysporum. Ethanol extract is seen to have the highest antifungal activity as it was able to inhibit the mycelia growth of Fusarium oxyporum (f.sp eleaidis) after the seven day period of observation. The extract with the closest inhibitory activity to Ethanol extract is Diethyl ether extract. When the activities of the two extracts were compared individually to that of the fungicide, the results were significantly better at $\mathrm{p}<0.05$ than fungicide. However, all extracts tested had better mycelia growth inhibition of F.oxysporum f.sp eleaidis than the positive control, Results on table 2 indicates that Hexane seed extract gave the best results with an inhibition of mycelia growth measurement of $1.55 \mathrm{~cm} \pm 0.05$ (SEM) on Hypocrea lixii (501885) than all the extracts after seven days of observation. This is followed by Ethanol extract with a mycelia growth measurement of $1.70 \mathrm{~cm} \pm 0.00$ (SEM). The antifungal activity of all the seed extracts was higher than the two controls.

The isolate that responded best to all the seed extracts is Hypocrea lixii (IMI 501885) as it had the least mycelia growth rate. Mancozeb. 
Table 3 shows the results of the percentage inhibition of each extract on the two isolates after seven days.

\begin{tabular}{lllllll}
\hline ISOLATES & ACETONE & ETHANOL & METHANOL & HEXANE & DIETHLETHER & FUNGICIDE \\
\hline F. oxysporum & 45.45 & 52.73 & 48.18 & 50.00 & 50.91 & 34.55 \\
H. lixii & 44.87 & 56.41 & 42.31 & 60.26 & 53.85 & 35.90 \\
\hline
\end{tabular}

$*$ Values are represented in percentages \%

From the results on table 3 , it can be clearly observed that generally, all the extracts had a significantly higher antifungal effect $(p<0.05)$ than the broad spectrum fungicide, Mancozeb. However, the extract that gave the highest percentage inhibition for Fusarium oxysporum (f.sp elaeidis) was the polar solvent of Ethanol seed extract with a percentage inhibition of $52.73 \%$ while the highest percentage inhibition for Hypocrea lixii was non polar Hexane seed extract with a percentage inhibition of $60.26 \%$. Amongst all the extracts used in this study, the seed extracts that gave the least percentage inhibitions are the Non polar Acetone seed extract on $F$. oxporum (f.sp elaeidis) with a low percentage activity of $42.45 \%$ and Methanol extract on $H$. lixii with a low percentage inhibition of $42.31 \%$.

Figures 1.0a and 1.0b shows the graphical representation of the growth pattern of each isolate (mean values were used for the plots) over the period of seven (7) days in response to treatment with each extract as well as the positive control, fungicide and that of dimethyl sulphoxide, the negative control

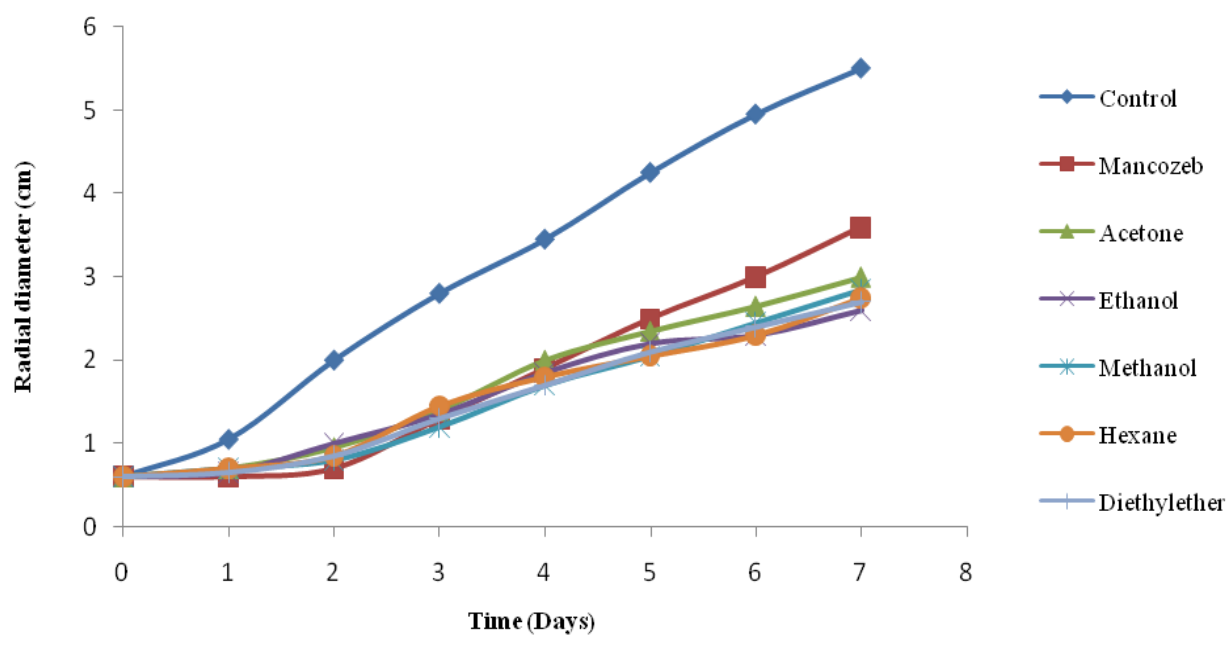

Fig 1.0a: Effect of extracts of Aframomum sceptrum on Fusarium oxysporum

From the growth pattern on the graph above (fig 1.0a), the two controls had little inhibition on the mycelia growth of the pathogen. This inhibition pattern was closely followed by acetone extract, then
Methanol and hexane exrtracts and Diethylether extracts. The extract with the best inhibition on $F$. oxysporum f.sp elaeidis was ethanol extract 


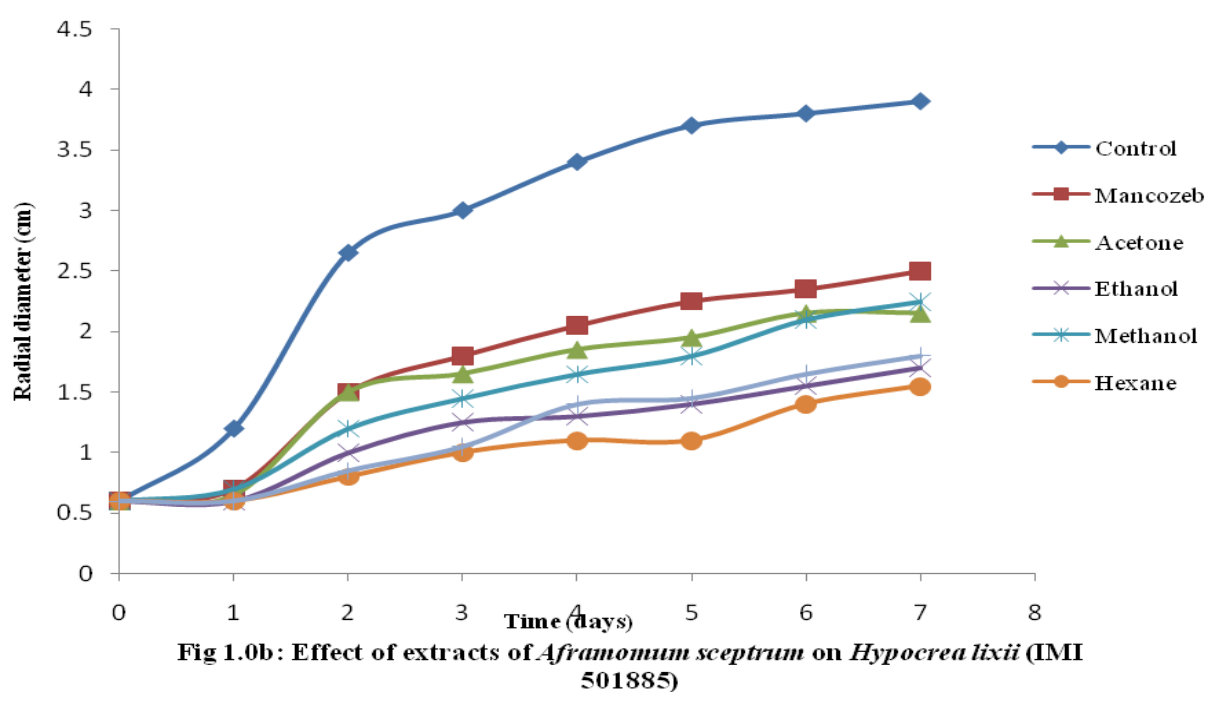

On fig 1.0b, the activities of all the extracts can be clearly seen as inhibitory although at different rates. All extracts had lower inhibitory growth pattern than the fungicide. It is also observed that the negative control and protic solvent did not have any inhibitory

effect on the growth rate of the fungus as shown by the uninhibited growth rate of the isolate. Phytochemical screening: The results for the phytochemical screening are represented on table 3 below

Table 3: Quantitative phytochemical screening of polar and non polar extracts of A.sceptrum

\begin{tabular}{lcccccc}
\hline Extracts & $\begin{array}{c}\text { Alka } \\
(\boldsymbol{\%})\end{array}$ & $\begin{array}{c}\text { Terp } \\
(\mathbf{M g} / \mathbf{1 0 0 g})\end{array}$ & $\begin{array}{c}\text { Anthra } \\
(\mathbf{M g} / \mathbf{1 0 0 g})\end{array}$ & $\begin{array}{c}\text { Flav } \\
(\%)\end{array}$ & $\begin{array}{c}\text { Tanins } \\
(\%)\end{array}$ & $\begin{array}{c}\text { Saponins } \\
(\mathbf{M g} / \mathbf{1 0 0 g})\end{array}$ \\
\hline ETH & 4.59 & 17.50 & 12.50 & 2.15 & 7.00 & 7.00 \\
MET & 4.32 & 15.00 & 21.00 & 1.94 & 4.05 & 22.00 \\
ACE & 12.39 & 10.50 & 25.00 & 1.50 & 1.95 & 18.00 \\
DEE & 4.97 & 20.00 & 15.00 & 1.80 & 0.945 & 2.00 \\
HEX & 18.69 & 25.50 & 19.00 & 1.14 & 9.39 & 4.50
\end{tabular}

KEY: ETH, Ethanol; MET, Methanol; ACE, Acetone; DEE, Diethylether and HEX, Hexane. Alka, Alkaloids; Terp., Terpenoids, Anthra,Anthraquinones, Tanins, Saponins.

From the results on table 3 , the following is observed; the highest percentage of Alkaloids was present in Hexane seed extract with a percentage of $18.69 \%$ with the least amount of alkaloids $(4.32 \%)$ present in Methanol seed extract. Terpenoids had highest concentration of $25.50 \%$ in Hexane extract and the least concentration in acetone extract with $10.50 \%$. Amount of Anthraquinones in the seeds of A.sceptrum was highest in acetone extract with an amount of $25.00 \mathrm{mg} / 100 \mathrm{~g}$ while concentration of Anthraquinones in Ethanol extract was $12.5 \mathrm{mg} / 100 \mathrm{~g}$. Ethanol solvent extracted $7.00 \%$ of Tannins from the seeds of this spice while hexane extract gave a percentage of Tanins as $9.39 \%$ and this was the highest concentration of tannins in all the extracts used as diethylether gave the least amount of tannins with a percentage $0.945 \%$.The percentage of Flavonoids was highest in ethanol extract with a concentration of $2.15 \%$ which was higher than the rest extracts and a concentration of $1.14 \%$ was observed in hexane extract which gave the lowest concentration of Favonoids. Lastly, the extract of methanol was highest with Saponins at $22.00 \mathrm{mg} / 100 \mathrm{~g}$ concentration and Diethylether the least whose amount of Saponins was analysed to be $2.00 \mathrm{mg} / 100 \mathrm{~g}$.

The graphs on Fig 2a-2f below shows the types and amounts of phytochemicals present in the Five polar and non polar extracts used for this study. 

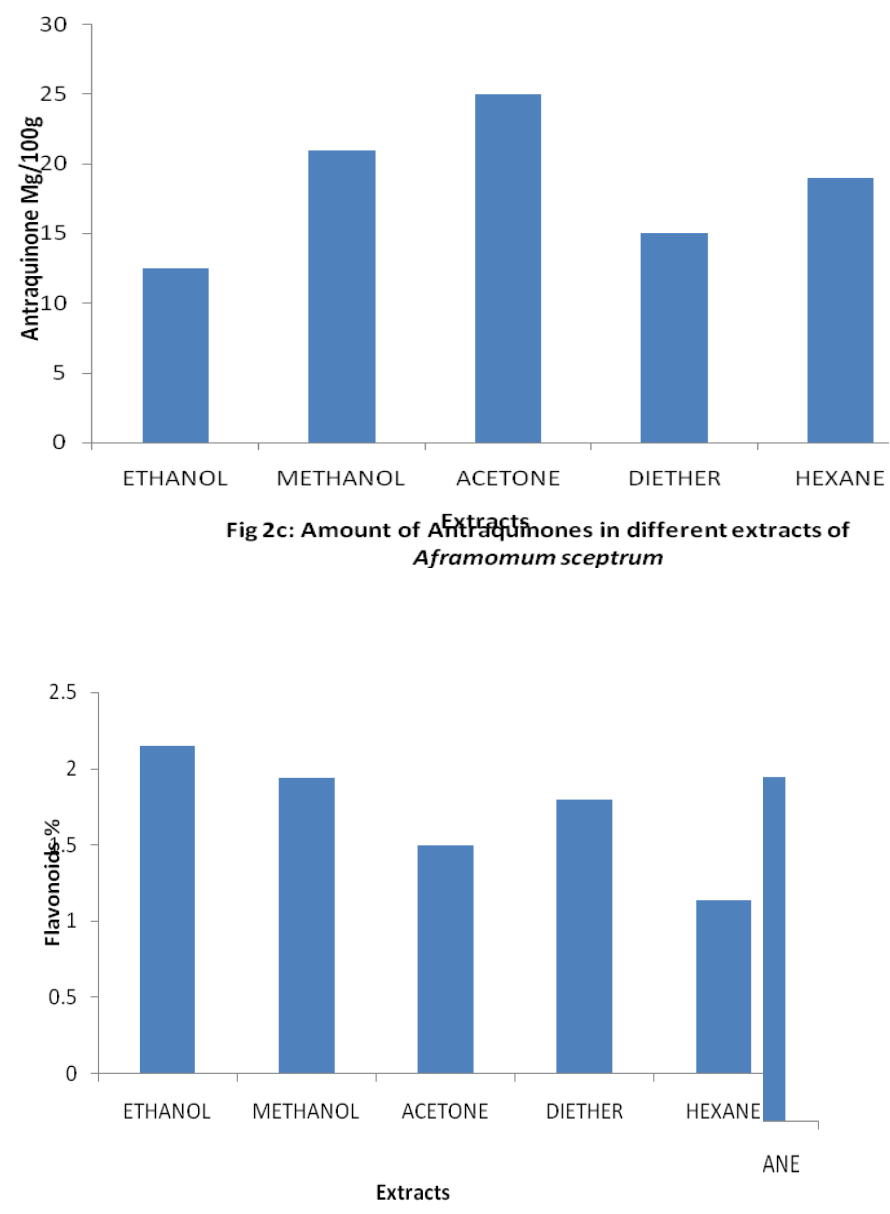

Fig 2d: Amount of Flavonoids in different extracts of Aframomum sceptrum sceptruIII acts of Aframomur

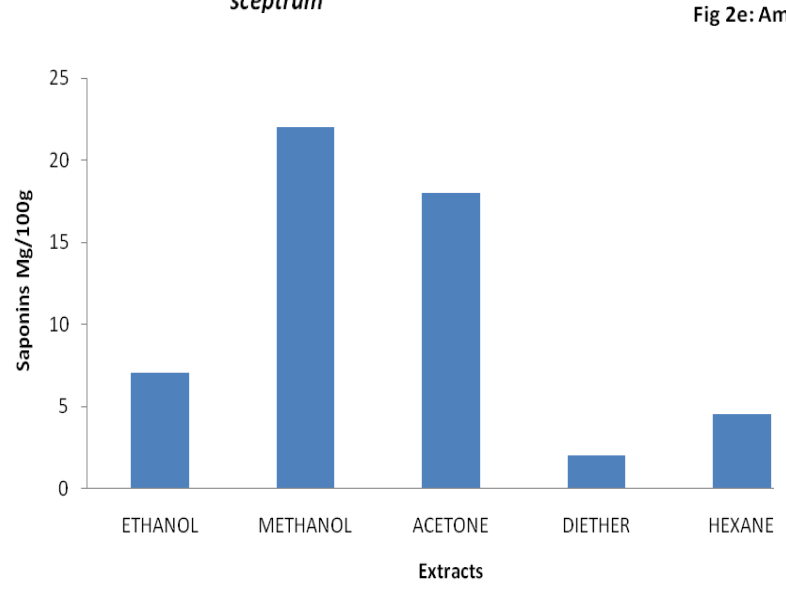

Fig 2f: Amount of Saponins in different extracts of Aframomum sceptrum 
Conclusion: This study clearly shows the antifungal potentials of Aframomum sceptrum on two economic important pathogens of the Oil palm. The presence of various active ingredients (secondary plant metabolites) Okigbo and Emoghene, A.O. (2003) as revealed by the phytochemical screening (table 3.0) supports the resourcefulness of plant extracts of Aframomum sceptrum against some plant isolates (Sofowora, 1993). The variations in performance of the extract on each test organism may be as a result of possible synergistic interactions between the active components in the extracts as well biodiversity of the isolates. There is therefore need to harness the potential of this common spice which is eco friendly and biologically degradable to control plant pathogens in nursery fields and on a large scale as it would help ameliorate the negative effects of continuous use of synthetic fungicides.

Acknowledgments The authors wish to thank the Executive Director, Dr. E. Asemota, Nigerian Institute for Oil Palm Research (NIFOR) for providing sponsorship to undertake this project.

\section{REFERENCES:}

Abou-Zeid A.M., Altalhi, A. D. and Abd El-Fattah, R.I. (2008). Fungal Control of Pathogenic Fungi Isolated From Some Wild Plants in Taif Governorate, Saudi Arabia. Mal .J. Microbiol. 4(1): 30-39.

Aderungboye, F.O (1982). Significance of vascular wilt in oil palm palm plantation in Nigeria. The Oil palm and agriculture in the eighties. ( Ed. Pushparajah and chew PS), Incorp. Soc. Planters, Kuala Lumpur, (2). pp. 475-484.

Agarwal, S.K., Singh S.S., Verma, S. and Kumar, S. (2000). Antifungal activity of anthraquinone derivatives from Rheum emodi. J. Ethnopharmacol. 72(1-2):43-6.

Baligar, P. N. and Kaliwal, B. B. (2001). Induction of gonadal toxicity to female rats after chronic exposure to mancozeb. Ind. Health, 39: 235-243.

Bautista, B.S., García, E., Barrera, L., Reyes, N. and Wilson, C. (2003). Seasonal Evaluation of the postharvest fungicidal activity of powders and extracts of huamúchil (Pithecellobium dulce): action against Botrytis cinerea, Penicillium digitatum and Rhizopus stolonifer of strawberry fruit. Postharvest Biology \& Technology, 29(1)8192.

Cantrell, C.L., Schrader, K.K., Mamonov,L.K., Sitpaeva, G.T., Kustova, T.S., Dunbar, C. and Wedge, D.E. (2005). Isolation and identification of antifungal and anti algal alkaloids from Haplophyllum sieversii. Agric. Food Chem. 53(20):7741-7748.

Chaverri, P. and Samuels, G.J. (2002). Hypocrea lixii Pat., the teleomorph of Trichoderma harzianum Rifai. Mycol. Prog. 1:283-286.

Cheikh, Z.A., Adiko, M., Bouttier, S., Boriesa, C., Okpekond, T., Poupona, E. and Champy, P. (2011). Composition and Antimicrobial and Remarkable Antiprotozoal Activities of the essential oil of rhizomes of Aframomum sceptrum K. Schum. (Zingiberaceae), Chem. and Biodiversity 8: 658-667.

Cirumalla, R.G., Sharan, M. and Sharon, M. (2011). Euro. J. Exp. Bio. 1(2):17-22.

Corley, R.H.V and Tinker, P.B. (2003).The oil palm ,fourth edition. Blackwell publishing, Oxford. pp 133- 198.

Cousins, D. and M.A. Hoffman. (2002). Medicinal properties in the diet of gorillas: An ethnopharmacological evaluation. Afr. Study Monographs. 23: 65-89.

De Franqueville H, (1984). Vascular wilt of the oil palm; relationship between nursery and field resistance. Oleagineux. 39: 513-518.

De Marco, E., Savarese, M., Parisini, C., Battimo, I., Falco, S. and Sacchi, R. (2007). "Frying performance of a sunflower/ palm oil blend in comparison with pure palm oil". Euro. J. Lipid Sci. Tech. 109 (3): 237.

EFSA - European food safety authority. Annual Report on Pesticide Residues. EFSA Scientific Report (2009). 305:1-106. 
Fasoyiro, S.B. and Adegoke, G.O. (2007). Phytochemical characterization and the antimicrobial property of Aframomum denielli. Afr. J. Agric. Res. 2(3): 076-079.

Figen Mert-T.rk. (2006). Saponins versus plant fungal pathogens J. Cell. Mol. Bio. 5: 13-17.

Flood, J. (2006). A review of Fusarium wilt of the oil palm caused by Fusarium oxysporum f. sp. elaeidis. Phytopath. 96 (6), 660-662.

Gomathi, S. and Ambikapathy, V. (2011). Adv. Appl. Sci. Res. 2 (4):291-297.

Ghani, A. (1998). Medicinal plants of Bangladesh, pp. 78-83. (Dhaka: Asiatic Society of Bangladesh).

Ghosh, A. (2009). Intl. J. Food Microbiol. 33 (1): 85102.

Harborne, J.B. (1998). Phytochemical Methods - A Guide to Modern Techniques of Plant Analysis. Chapman and Hall, London, pp. 182- 190.

Harman, G.E., Howell, C.R, Viterbo, A., Chet, I and Lorito, M. (2004). Trichoderma speciesopportunistic, virulent plant symbionts. Nat.Rev.Microbiol., 2(1): 43-56.

Harminder, S., Rajinder, Singh, Abduh, R.., Rahimah, Ooi, Cheng, Li, Low, Eng, and Ti (2010). Method for identification of a molecular marker linked to the shell gene of oil palm. PCT/MY2009/000192, International application published under the Patent Cooperation Treaty (PCT), World Intellectual Property Organization International Bureau. International publication.

Hartley, C. W. S. (1988). The oil palm (Elaeis guineensis Jacq.), 3rd ed. Longman scientific and technical Essex, UK. 761 p.

Ho, Y.W. and Varghese, G. (1986). Pathogenic potential of soil Fusaria from Malyasia oil palm habitats. J. Phytopathol.115: 325-328.
Kackar, R., Srivastava, M. K. and Raizada, R. B. (1997). Studies on rat thyroid after oral administration of mancozeb: Morphological and biochemical evaluations. J. Appl. Toxicol. 17:369-375.

Kinkel, L.L and Andrews, J.H. (1988). Disinfestation of living leaves by hydrogen peroxide. Trans. $B r$. Mycol. Soc. 91: 523-528.

Loizzo, M. R.; Statti, G. A. Tundis, R.; Conforti, F. Bonesi, M. Autelitano, G. Houghton, P. J. Miljkovic, A. and Menichini, F. (2004). Antibacterial and antifungal activity of Senecio inaequidens DC. and Senecio vulgaris $\mathrm{L}$. Phytother. Res. 18: 777-779.

Min, B. R., Pinchak, W. E., Merkel, R., Walker, S., Tomita, G. and Anderson, R. C. (2008). Comparative antimicrobial activity of tannin extracts from perennial plants on mastitis pathogens. Sci. Res. Essay. 3(2): 066-073.

Muhsin, T.M., Al-Zubaidy S.R. and Ali. E.T. (2001). Effect of garlic bulb extract on the growth and enzymatic activities of rhizosphere and rhizoplane fungi. Mycopathologia, 152(3):143146.

Nair, R.V., Odewale J.O., and Ikuenobe, C.E. (2003). Coconut Nursery Manual Published by Nig. Inst. Oil palm Res. 3-22.

Neerja, G., Goldy S. and Kalra, S.S. (2011). Antimicrobial activity pattern of certain terpenoids. Int.J. Pharma. Bio. Sci. 2 (1): 87-91.

Nelson, P.E, Dignani, M.C and Anaissie, E.J. (1994). Taxonomy, biology and clinical aspects of Fusarium species. Clin. Microbiol. Rev. 4: 479504.

Nene, Y. and Thapilyal, L. (2000). Poisoned food technique of fungicides in plant disease control 3rd Edn. Oxford and IBH Publishing Company, New Delhi. 
Novak, K.M., ed. (2002). Drug facts and comparisons $\left(56^{\text {th }}\right.$ ed.). St. Louis, Missouri: Wolters Kluwer Health.p. 619. ISBN 1-57439110-0.

Obagwu, J., Emechebe, A.M. and Adeoti, A.A. (1997). Effects of extracts of Garlic (Allium sativum L.) bulb and Neem (Azadirachta indica Juss.) seed on the mycelia growth and sporulation of Colletotrichum Capsici (syd) Butler and Bisby. J. Agric. Tech. 5(1): 51-55.

Obi, I. U. (2002). Statistical Methods of Detecting Differences between Treatment Means and Research Methodology Issues in Laboratory and Field Experiments. $2^{\text {nd }}$ edition. Ap express publication, Ltd. Nsukka, Nigeria.

Oil world annual report (2008).

Okigbo, R.N. and Emoghene, A.O. (2003). Effect of leaf extract of three plant species on Mycosphaerella fijiensis Morelet, the causal organism of Black Sigatoka disease of Banana (Musa acuminata). Niger. J. Pl. Prot., 20: 101110.

Okwu and Omodamiro, O.D. (2005). Effects of Hexane extracts and phytochemical content Xylopia aethiopica and Ocimum gratissimum on the uterus of guinea pig. Bio-Res. 3:30-37.

Okwu, D.E and Ekeke, O.(2003). Phytochemical screening and mineral composition of chewing sticks in south Eastern Nigeria. Global J. pure App. sci. 9: 235-238.

Qudsia, K., Ishtiaq, H., Hamid, L. S. and Arshad, J. (2010). Antifungal activity of flavonoids isolated from mango (Mangifera indica L.) leaves. Nat. Prod. Res. 24(20): 1907-1914.

Ravi Menon, N., Zulkifli Ab Rahman and Nasrin Abu Bakar. (2003) "Empty Fruit Bunches Evaluation: Mulch in Plantation vs. Fuel for Electricity Generation", Oil Palm Ind. Eco. J. 3:2
Simon, H. (2008) '"Those that are Cooking the Gins": The Business of Ogogoro in Nigeria', Contemporary Drug Problems, 35(4): 573-610.

Singh, J. and Tripathi, N.N. (1999).Inhibition of storage fungi of blackgram (Vigna mungo) by some essential oils. Flavour Frag. J. 14:1 - 4.

Singh, S., Taneja, M, and Majumdar, D.K. (2007). Biological activities of Ocimum sanctum L. fixed oil - an Overview. Indian J. Exp. Biol. 45(5): 403412.

Sofowora, A., 1993.Medicinal Plants and Traditional Medicine in Africa. John Wiley and son Ltd., 150153.

Summerell, B.A.,Baharuddin, S. and Leslie, F.J. (2003). A Utilitarian Approach to Fusarium Identification. Ame. Psychopathol. Soc. Pl. Dis. 87: 117-128.

Tengoua, F. F. and Bakoumé, C. (2008). Pathogenicity of Cameroon strains of Fusarium oxysporum $f$. sp. elaeidis - the causal agent of oil palm vascular wilt. The Planter, 84(985):233-237.

Trease, G.E. and W.C. Evans, 1989. Pharmacognosy. 11th Edn. Brailliar Tiridel and Macmillian Publishers, London.

Wardlaw, C.W., (1946). Fusarium oxysporum on the oil palm. Nature. pp. 158-712.

Zachow, C., Berg, C., Müller, H., Meincke, R.,Komon-Zelazowska, M., Druzhinina, I.S., Kubicek, C.P. and Berg, G. (2009). Fungal diversity in the rhizosphere of endemic plant species of Tenerife (Canary Islands): relationship to vegetation zones and environmental factors. ISME J., 3:79-92. 